Article

\title{
Fossilization History of Fossil Resin from Jambi Province (Sumatra, Indonesia) Based on Physico-Chemical Studies
}

\author{
Beata Naglik ${ }^{1}$, Barbara Kosmowska-Ceranowicz ${ }^{2}$, Lucyna Natkaniec-Nowak ${ }^{3}$, \\ Przemysław Drzewicz 4 (D), Magdalena Dumańska-Słowik 3,* (D), Jakub Matusik ${ }^{3}$, \\ Marian Wagner ${ }^{3}$, Rastislav Milovsky ${ }^{5}$, Paweł Stach ${ }^{3}$ and Arkadiusz Szyszka ${ }^{3}$ \\ 110 Beskidzka Str., 34-312 Międzybrodzie Żywieckie, Poland; beata.naglik@op.pl \\ 2 The Museum of the Earth of the Polish Academy of Sciences in Warsaw, 20/26 Na Skarpie Str., \\ 00-488 Warsaw, Poland; mzamber@poczta.onet.pl \\ 3 Department of Mineralogy, Petrography and Geochemistry, AGH University of Science and Technology, \\ Av. Mickiewicza 30, 30-059 Krakow, Poland; natkan@agh.edu.pl (L.N.-N.); jmatusik@geol.agh.edu.pl (J.M.); \\ m.wagner43@upcpoczta.pl (M.W.); ppawel.stachh@gmail.com (P.S.); arek.szyszka@interia.pl (A.S.) \\ 4 The Polish Geological Institute-National Research Institute, 4 Rakowiecka Str., 00-975 Warsaw, Poland; \\ przemyslaw.drzewicz@pgi.gov.pl \\ 5 Earth Science Institute, Slovak Academy of Sciences, 1 Ďumbierska Str., 974-11 Banská Bystrica, Slovakia; \\ milovsky@savbb.sk \\ * Correspondence: dumanska@agh.edu.pl; Tel.: +48-126172380
}

Received: 27 December 2017; Accepted: 27 February 2018; Published: 2 March 2018

\begin{abstract}
A unique specimen of fossil resin originating from the Dipterocarpaceae tree family found in Miocene brown coal deposits in Jambi Province (Sumatra, Indonesia) was investigated via microscopic observations, microhardness testing and infrared and Raman spectroscopic methods. Its form is rare in nature, being an aggregate of three varieties of resin differing in colour, transparency and internal structure. This suggests the formation of the resins at different stages. Further alteration processes, including fossilization and maturation of the resin in a swamp environment resulted in stepwise aromatization of the cyclohexane ring in steroids and cross-linking through formation of ester bonds as well as carbon-carbon bonds between steroid molecules. The various environmental and geological conditions affecting the formation processes of the resins were recorded in their physico-chemical properties. Additionally, heating conditions accelerated by volcanism were proposed as a factor determining the maturation grade of the resin.
\end{abstract}

Keywords: fossil resins; Sumatra; Indonesia; FT-IR; Raman spectroscopy; microhardness; maturation

\section{Introduction}

The natural resins (fossil or modern) are caustobioliths, genetically belonging to the group of liptobiolites [1]. Regardless of their provenance or their geological environment and age, they are products of the defence mechanisms of both coniferous and angiosperm trees and were formed millions of years ago. They are found in sedimentary rocks from the Devonian to the Cenozoic; however, they are mostly accumulated within the Palaeogene to Neogene sediments [2]. Resins were very often transported from primary deposits to younger geological layers. In these cases, resin dating is disputable and uncertain. The accumulation of amber in deposits of various ages is related to a period of increased resin production caused by various environmental and geological conditions, for example volcanic activity [3]. Forest fires and pest infestation caused by climate change may also increase resin production. The intense resin exudation from trees was usually part of the self-protection mechanisms of various plants. The chemical and physical properties of fossil resins depend primarily 
on their botanical source; nevertheless, various environmental and geological conditions occurring during fossilization may also affect the resins [2,4-6]. As an example, one can cite redox conditions after burial, which influence the alteration of organic matter [5]. Later transformations are accelerated by temperature and pressure conditions during diagenesis and/or catagenesis; however, the duration of heating is also important [5]. Knowledge of the composition and physical properties of resins allows their botanical affinity to be determined and their evolutionary history to be reconstructed from the time of their formation through their transportation and final fossilization processes.

Preservation of fossil resins depends on how fast they were buried and isolated from oxygen, sunlight and biological conditions, together with other factors causing their biodegradation [2]. For example, sandy sediments allowing water migration are not suitable for organic matter preservation [5]. Therefore, many fossil resins are found within coal deposits formed under reducing, anaerobic conditions, such as the world's largest fossil resin deposit located on the island of Borneo-in both the Malaysian and Indonesian parts [7]. This deposit is found within coal beds of Miocene age. Similar conditions occurred in coal deposits located in South Sumatra.

Fossil resins from Sumatra were formed from exudates of the Dipterocarpaceae family, belonging to the angiosperm group of trees, particularly from the genera Shorea and Hopea [8-10]. According to [11], Sumatran fossil resins may be distinguished from resins from other localities worldwide (Baltic, Dominican and Myanmar resins) based on distinctive inclusion characteristics (numerous round and oval-shaped droplets) and a diagnostic mid-IR spectrum. However, it must be noted that the presence of droplets is not characteristic only of Sumatran resin. They have also been described in Triassic fossil resins from Italy [12] and French Cretaceous resins [13]. The presence of fossil insects and plants in the Sumatran resins has not been detected in previous studies [11]. A detailed description of the internal structures and forms of Sumatran fossils was given in [3]. The FT-IR characteristic of the specimens, as discussed in [14], revealed their similarity to resins of the glessite type, found in the Bitterfeld deposit (Saxony-Anhalt, Eastern Germany) (vide [15-18]).

The aim of the study was to reconstruct the fossilization history of a fossil resin specimen from the island of Sumatra (Jambi Province) via microscopic observations, microhardness testing and infrared (FT-IR) and Raman spectroscopy (RS). The specimen is a unique aggregate of three different resin varieties distinguishable on the basis of their colour, transparency and internal structure. This allowed us to examine the alteration processes of those resins from the time of their formation to their present-day form.

\section{Materials and Methods}

\subsection{Sampling}

The samples of fossil resin originate from the south part of the island of Sumatra, $15 \mathrm{~km}$ south of Jambi city (Sarolangun mine). The size of Sumatran resins varies from very small, with a diameter of a few $\mathrm{mm}$, to very large, weighing up to several hundred grams. Larger specimens of Sumatran resin are usually aggregates of three different types of resin (Figure 1). These three varieties of Sumatran resin were individually analysed with stereoscopic and polarizing microscopes, microhardness testing and finally, spectroscopic analysis (FT-IR and RS). Microscopic observations, microhardness measurements and FT-IR analyses were conducted at laboratories at the Faculty of Geology, Geophysics and Environmental Protection, AGH University of Science and Technology, Krakow (Poland) and Slovak Academy of Sciences, Banská Bystrica (Slovakia). Raman spectra were recorded at Tusnovics Instruments SP, Krakow (Poland).

\subsection{Microscopic Methods}

The internal structures of resins were observed using a stereoscopic microscope SNZ-168, coupled with a digital camera (with $0.75 \times, 1 \times, 2 \times, 3 \times, 4 \times$ and $5 \times$ objectives), in conjunction with the Panasis computer program. Standard optical examinations were carried out with an Olympus BX 51 
polarizing microscope (Tokyo, Japan). Organic inclusions were observed using a polarizing microscope (Axioplan, Zeiss-Opton, Oberkochen, Germany) in the reflected light mode. For the microscopic observations thin sections were made.

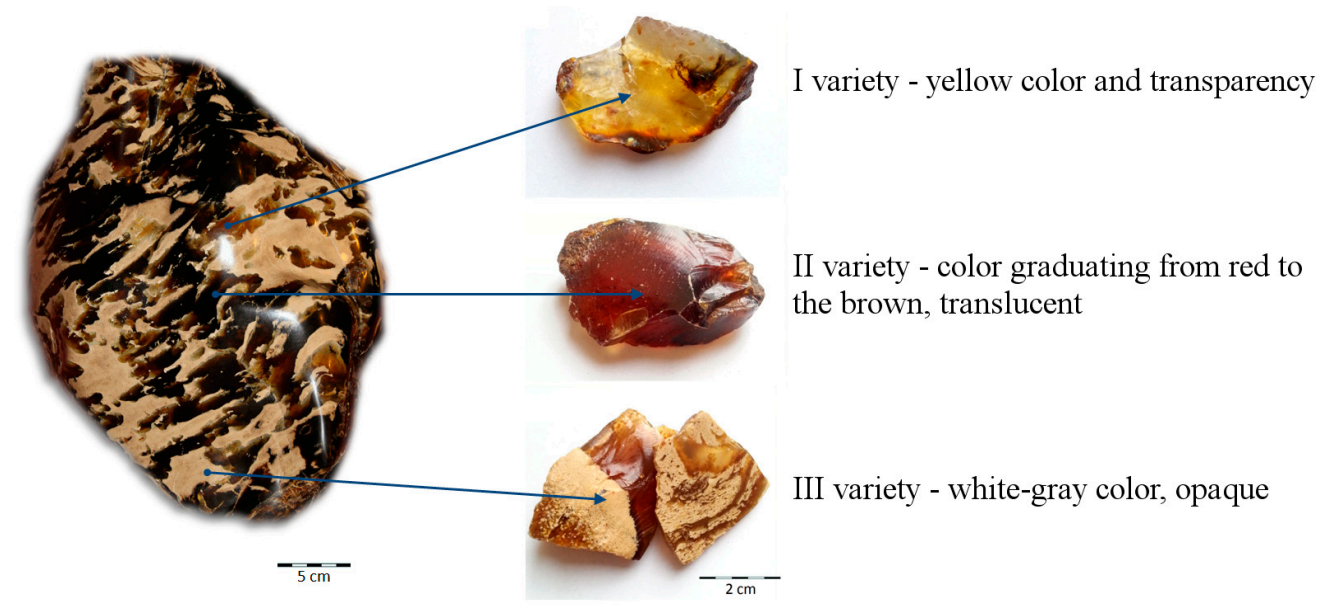

Figure 1. Samples of three varieties of Sumatran resin taken from its aggregate.

\subsection{Microhardness Measurements}

Microhardness measurements were performed using the Russian microhardness tester PMT-3. The Vickers hardness test was performed using the mode in which the microhardness HV $\left(\mathrm{kG} / \mathrm{mm}^{2}=9,806,650 \mathrm{~Pa}\right)$ is determined by the ratio $F / A$, where $F$ is the force applied to the sample by a square-based diamond pyramid of dihedral angle $136^{\circ}$ in kilograms-force and $A$ is the lateral area of the resulting indentation in square millimetres. A $250 \mathrm{mg}$ load was used for the measurements. The duration of the pressure of the diamond pyramid on the sample was $10 \mathrm{~s}$. The test was conducted on the smooth surface of all the varieties of the samples, repeating the measurement 30 times in different places on the samples. Microhardness was calculated based on the arithmetic average of the results.

\subsection{Spectroscopic Methods}

FT-IR analyses were performed using a Thermo Scientific Nicolet 6700 spectrometer (Madison, WI, USA). Spectra were recorded at room temperature in the range $400-4000 \mathrm{~cm}^{-1}$, with a resolution of $4 \mathrm{~cm}^{-1}$. A sample/ $\mathrm{KBr}$ mixture (3 $\mathrm{wt} \%$ ) was analysed using the DRIFT (Diffuse Reflectance Infrared Fourier Transform) technique with a Praying Mantis diffuse reflection accessory (Harrick, Pleasantville, NY, USA). The DRIFT technique gives a higher signal-to-noise ratio compared to the standard $\mathrm{KBr}$ pellet procedure. Obtained spectra were transformed using the Kubelka-Munk function and signal intensity is given in Kubelka-Munk units.

Raman spectra of fossil resins in the range $2000-200 \mathrm{~cm}^{-1}$ were recorded using a Rigaku Progeny ResQ spectrometer with a laser of wavelength $1064 \mathrm{~nm}$. The laser focus diameter was $1-2 \mu \mathrm{m}$.

\section{Geological Settings}

The samples of resins from the dumps of the Sarolangun mine (Figure 2A) were found within coal and lignite beds dating to the early Miocene (20-23 Ma) and belonging to numerous levels of the South Sumatra Basin, including the Talang Akar formation ([19]—vide Figure 2B).

The Talang Akar formation (TAF) represents the sedimentary cycle extending from the late Oligocene to the early Miocene [20]. The TAF succession represents a regressive unit, with shales and sandstones deposited in a fluvio-deltaic environment building the upper part of the formation profile [21]. This unit is overlain by the early and middle Miocene sediments representing 
transgressive depositional systems. All these formations were uplifted, folded and faulted due to the Pliocene-Pleistocene orogeny [20] associated with volcanic activity (Figure 2C,D). Fossil resins from Jambi Province occur in immature coal layers (lignite beds) [22].

The palaeoenvironment of Sumatra during the Tertiary period had a warm and humid climate. It was a part of southern Sundaland located within $\pm 10^{\circ}$ of the equator, with a palaeoclimate favourable for peat formation (Figure 2A) [22].
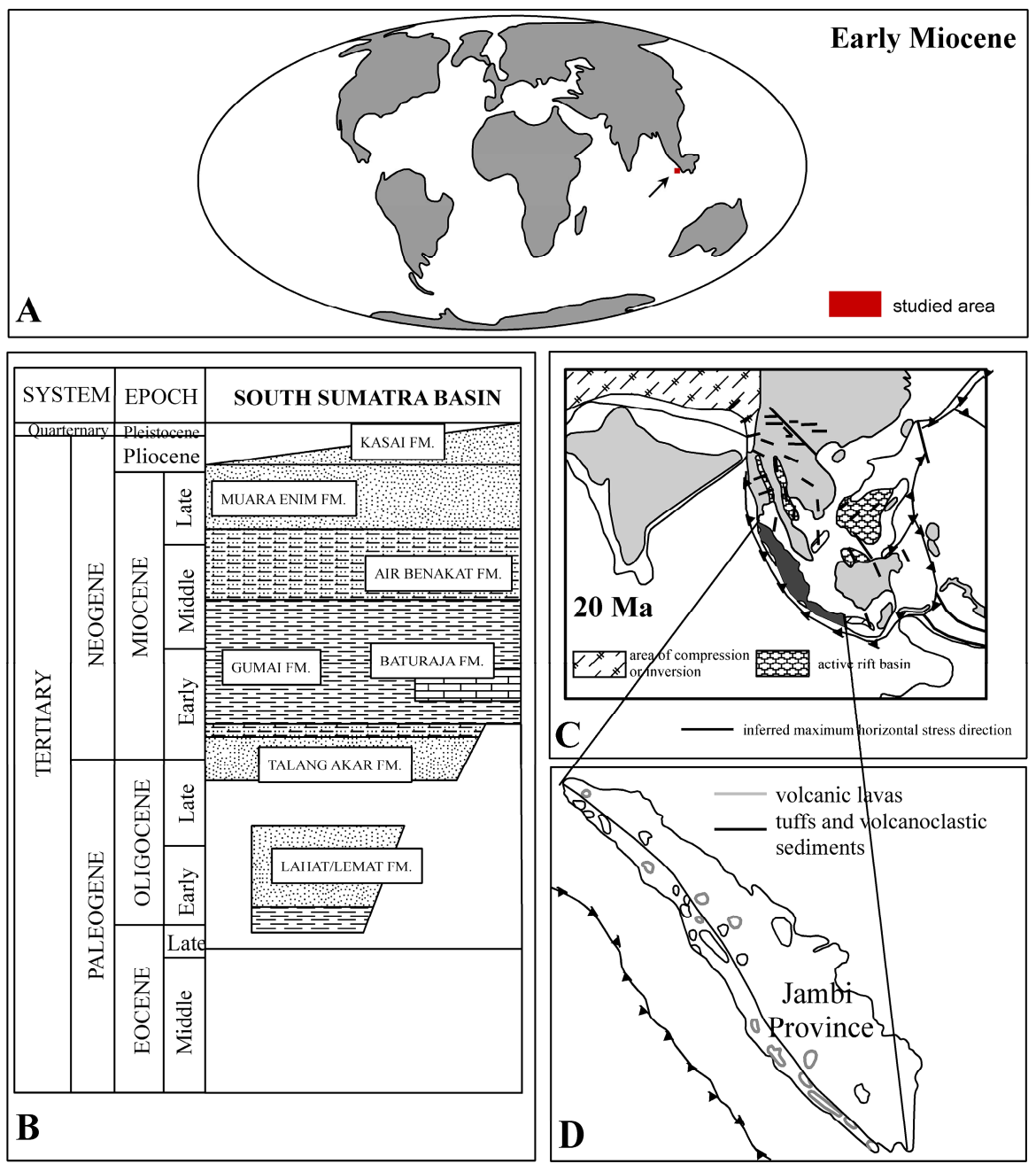

Figure 2. (A) tectonic map of Miocene world; (B) geological profile of South Sumatra Basin (on the basis of [23]); (C) Indonesia during Miocene epoch (modified after [22]); (D) volcanic units of the island of Sumatra (according to [23]).

\section{Results}

\subsection{Physical Investigations}

The three varieties within the sample of Sumatran resin (Figure 1, Table 1) were distinguished according to their physical properties, such as colour and transparency.

Under microscopic observation, the three resin varieties differ from each other with regard to their internal structures (Figure 3). Variety I is bright yellow, transparent and relatively clear, with only small amounts of inclusions (Figure 3A,B). Variety II is a dark, translucent resin. Small microdrops with sizes up to $150 \mu \mathrm{m}$ were observed. Small dark inclusions were probably particles of coalified plant material (Figure 3C,D). Variety III is an opaque resin with a solid foam-like structure containing droplets filled with variety I resin, previously described in [3] as a relic of volcanism (Figure 3E,F). 
In one sample, all three resin varieties were mixed together; however, the borders between them were distinctly marked (Figure 4).

Table 1. Macro- and microscopic characteristics of Sumatran fossil resins.

\begin{tabular}{cccc}
\hline Physical Property & Variety I & Variety II & Variety III \\
\hline Color & yellow & red to brown & white-gray \\
\hline Transparency & transparent & translucent & opaque \\
Structure & homogenous & $\begin{array}{c}\text { non-homogenous with } \\
\text { single droplets }\end{array}$ & $\begin{array}{c}\text { foamy-like with } \\
\text { numerous droplets filled } \\
\text { with resin of I variety }\end{array}$ \\
\hline Inclusions & $\begin{array}{c}\text { only locally-spherical plant } \\
\text { microspores or fragments of channels } \\
\text { of strongly macerated wood }\end{array}$ & $\begin{array}{c}\text { dispersed pigment of fungus } \\
\text { spores or pollen plants }\end{array}$ & coalified plant remains \\
\hline Fluorescence & low & low & intensive \\
\hline
\end{tabular}

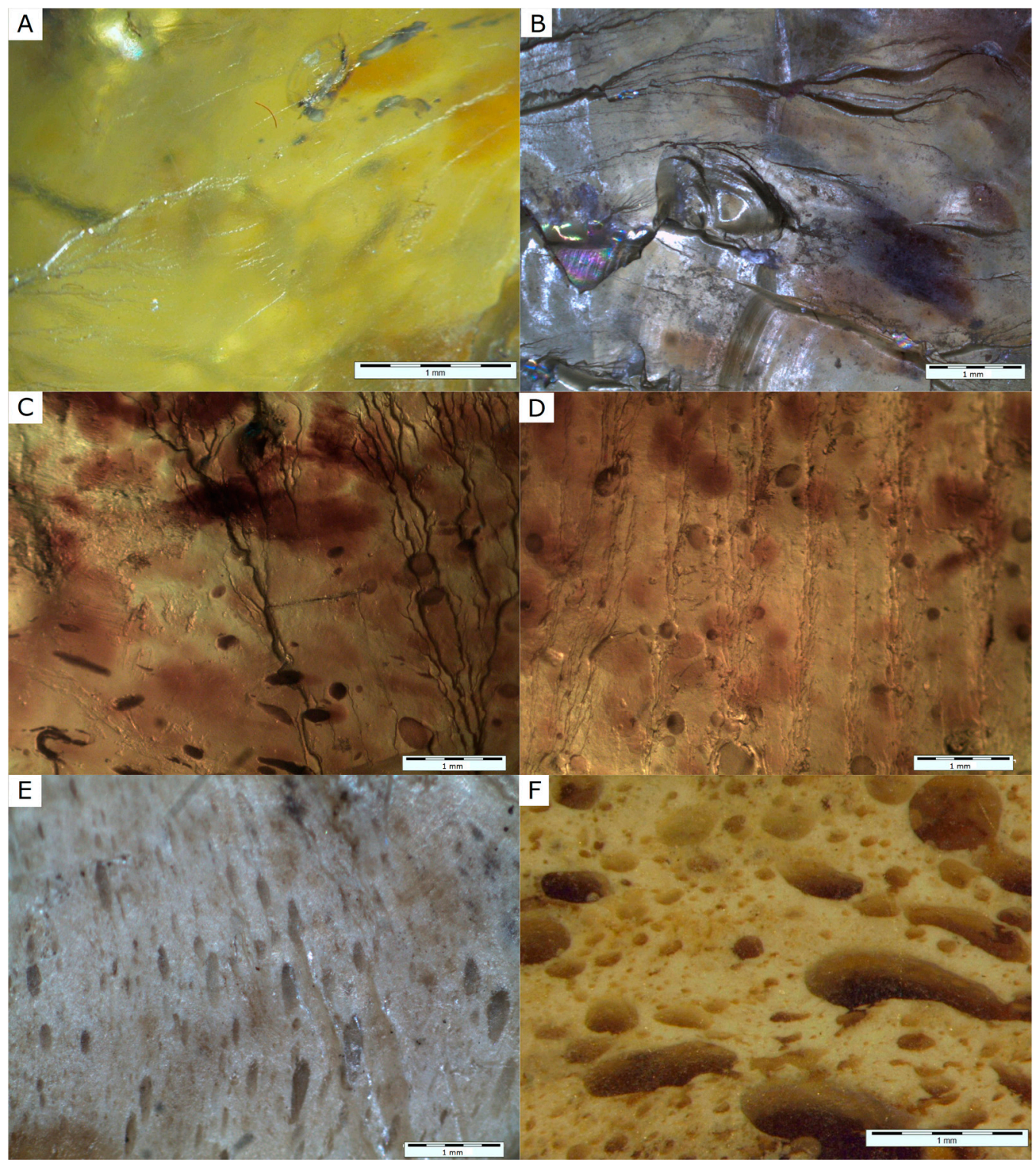

Figure 3. Stereoscopic photographs of samples; from the top: (A,B) bright yellow (variety I); (C,D) dark (variety II) and (E,F) opaque (variety III) of resins. 


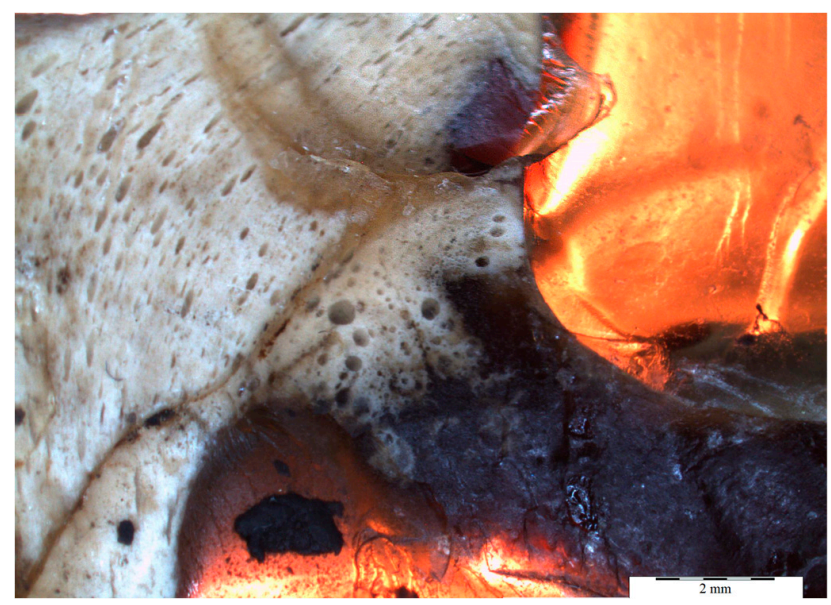

Figure 4. Stereoscopic photo of the contact zone between resin varieties II and III.

Under transmitted light, resin variety I showed the presence of coalified plant material with specific morphological shape and opacity. Spherical accumulations of organic material inclusions with preserved envelopes were observed. The inclusions resembled plant microspores or fragments of channels of strongly macerated wood. Resin variety II contained evenly distributed opaque detritus (Figure 5), probably fungus spores or plant pollen, both of which are relatively common in brown coal. This pigment is probably responsible for the darker coloration of this variety. Resin variety III contained evenly distributed microdroplets showing yellow colours with crossed polarizers, probably mineral substances of a lipid type (Figure 6). The presence of numerous elongated, oval microdroplets is responsible for the fluid microtexture of this variety (Figures 3E and 4).

In reflected light, all resin varieties show bright colour with low contrast. Furthermore, the resin varieties differ in their reflectivity. Microscopic observations confirmed the presence of coalified organic material with variable but generally low reflectivity.

In UV light (blue, unpolarized) Sumatran resins emitted variable fluorescence with the intensity depending on the variety. The strongest blue fluorescence was observed for resin variety III (Figure 7A,B), which was due to a sheath of droplets of variety I.

The calculated microhardness values were: $26.297 \pm 3.662$ (variety I), $24.304 \pm 4.780$ (variety II) and $24.232 \pm 4.631$ (variety III) $\mathrm{kG} / \mathrm{mm}^{2}$. There was no statistically significant difference between the microhardness measurements of all three specimens; however, variety I showed a slightly higher value than the other varieties.

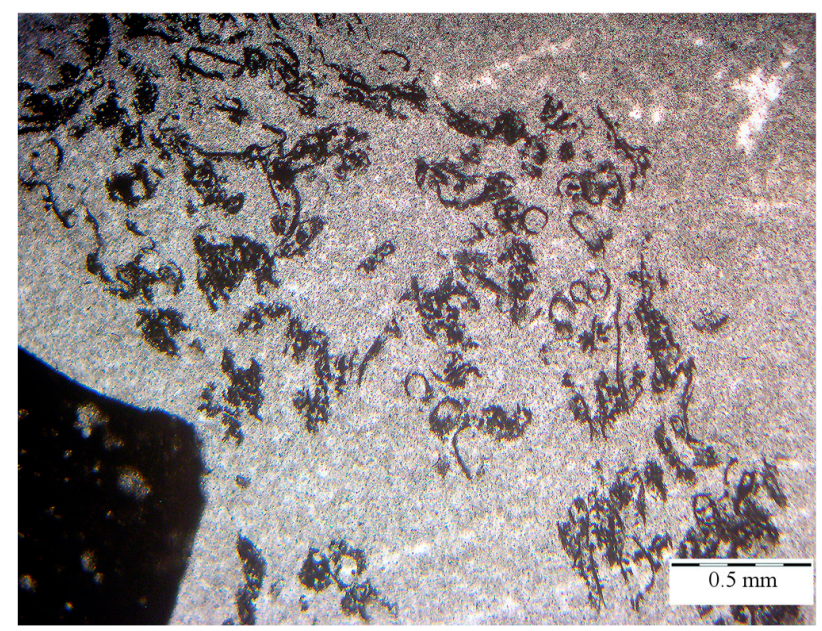

Figure 5. Microphotograph of organic detritus in resin variety II, polarized light; $1 \mathrm{~N}$. 


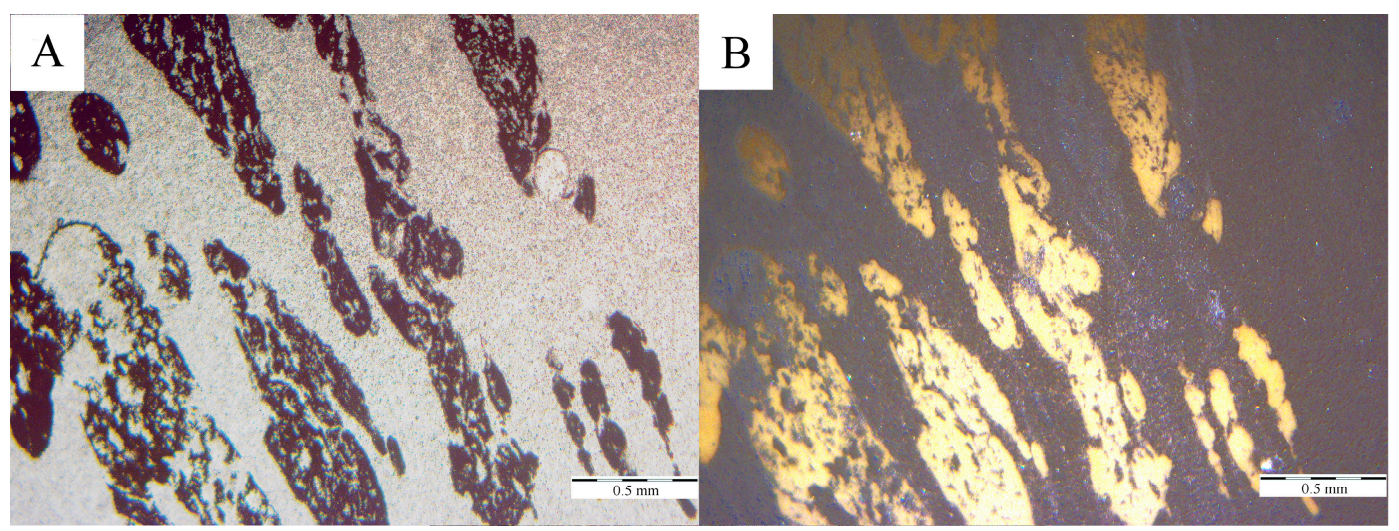

Figure 6. Microphotograph of resin variety III surrounded by variety II, polarized light; 1 N (A); NX (B).

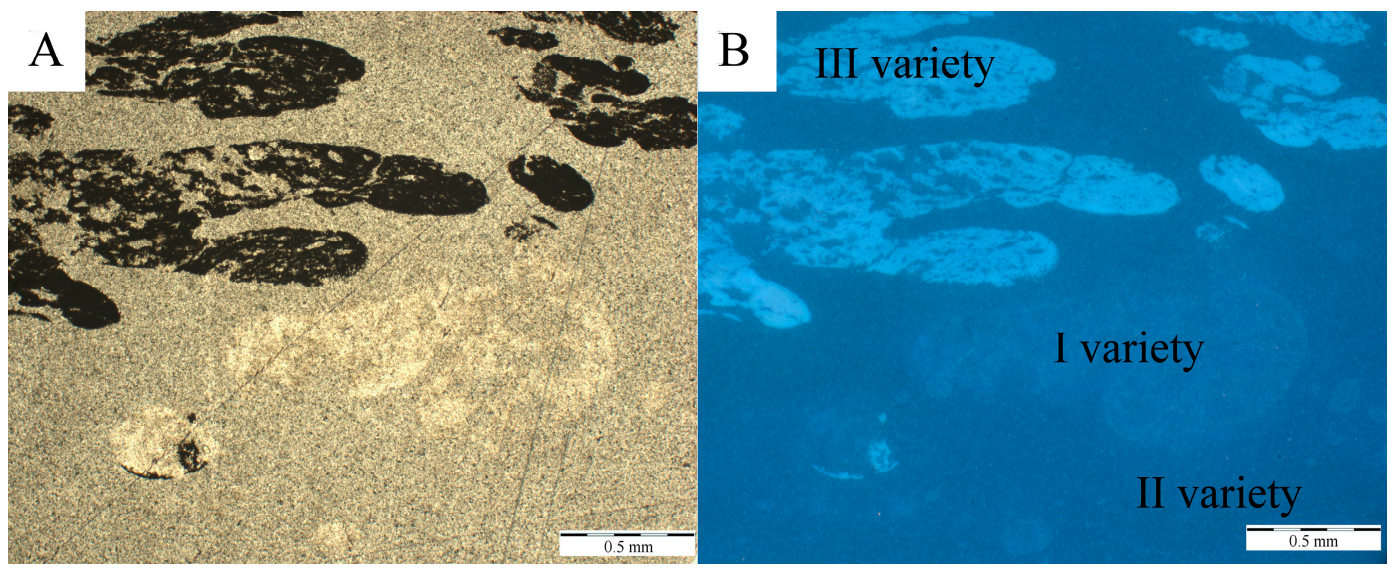

Figure 7. Microscopic image of fossil resins from the island of Sumatra, 1N (A); UV-epifluorescence (B).

\subsection{Spectroscopic Studies}

\subsubsection{FT-IR Analysis}

Resins are plant exudates; therefore, adsorption bands characteristic of hydrocarbons are present in their FT-IR spectra (Figure 8, Table 2). In the wavenumber region $3600-3200 \mathrm{~cm}^{-1}$, all spectra show a broad band with a maximum at $\sim 3400 \mathrm{~cm}^{-1}$ corresponding to the $\mathrm{OH}$ stretching vibrations in alcohols and carboxylic acids $[20,21]$. The most intense bands are attributed to $\mathrm{C}-\mathrm{H}$ stretching and bending vibrations observed in the $3000-2800$ and $1500-1350 \mathrm{~cm}^{-1}$ regions respectively. In the region $3000-2800 \mathrm{~cm}^{-1}$, three distinct bands are observed, probably corresponding to the alkyl stretching mode [24,25]; however, their shape differs in the spectra of the investigated samples (Figure 6). The latter region contains bands with maxima at $\sim 1456, \sim 1384$ and $\sim 1367 \mathrm{~cm}^{-1}$ which are exclusively related to $\mathrm{CH}_{2}$ and $\mathrm{CH}_{3}$ bending vibrations [24-26]. An important feature of the analysed resins is the presence of absorption bands in the $1800-1600 \mathrm{~cm}^{-1}$ region, corresponding to carbonyl group $(C=O)$ stretching vibrations [24-26]. Resin variety I has the most symmetrically shaped band with a maximum at $1690 \mathrm{~cm}^{-1}$ (Figure 6). The presence of more than one band in this region suggests that the $\mathrm{C}=\mathrm{O}$ group can be attributed to esters, ketones, carboxylic acids or even lactones. This is clearly observed in the spectra of varieties II and III. A band at $\sim 1730 \mathrm{~cm}^{-1}$ may be assigned to esters $[24,25]$. An important feature which differentiates variety I from the others is the lack of the $\sim 1600 \mathrm{~cm}^{-1}$ band which is probably related to aromatic compounds. There were no significant differences in the $1350-800 \mathrm{~cm}^{-1}$ region corresponding to vibrations of $\mathrm{C}-\mathrm{C}, \mathrm{C}-\mathrm{H}$ and $\mathrm{C}-\mathrm{O}$ (in esters) bonds. In variety I, the band at $\sim 1050 \mathrm{~cm}^{-1}$ is more visible. 
Table 2. FT-IR bands assignment.

\begin{tabular}{|c|c|c|c|}
\hline \multicolumn{3}{|c|}{ FT-IR Wave Numbers $\left(\mathrm{cm}^{-1}\right)$} & \multirow{2}{*}{ Assignment } \\
\hline I Variety & II Variety & III Variety & \\
\hline 825 & 825 & 825 & Aromatic ring $\mathrm{C}-\mathrm{H}-1,4$-Disubstitution (para) \\
\hline 888 & 888 & 888 & $\mathrm{CH}$ ethylenic bending [24] \\
\hline 975 & 975 & 975 & C-O bonds [24] \\
\hline 1033 & 1028 & 1027 & C-O bonds [24]; cyclohexane ring vibrations $\left(1000-1055 \mathrm{~cm}^{-1}\right)$ [27] \\
\hline 1048 & 1048 & 1048 & $\begin{array}{l}\text { Cyclohexane ring vibrations }\left(1000-1055 \mathrm{~cm}^{-1}\right) \text {; primary alcohol, } \\
\text { C-O stretching [27] }\end{array}$ \\
\hline 1167 & 1173 & 1174 & $\begin{array}{l}\text { C-O simple bond stretching of esters [26]; tertiary alcohol, } \\
\text { C-O stretching [27] }\end{array}$ \\
\hline 1199 & 1200 & 1200 & Phenol, C-O stretching [27] \\
\hline 1255 & 1255 & 1255 & Primary or secondary, OH in-plane bending [27] \\
\hline 1315 & 1315 & 1317 & Primary or secondary, OH in-plane bending [27] \\
\hline- & 1332 & 1339 & $\begin{array}{l}\text { Methane } \mathrm{C}-\mathrm{H} \text { bending }\left(1330-1350 \mathrm{~cm}^{-1}\right) \text {; primary or secondary, } \\
\text { OH in-plane bending [27] }\end{array}$ \\
\hline 1367 & 1367 & 1367 & Due to $\mathrm{CH}_{3}$ bending [24] \\
\hline 1377 & 1378 & 1377 & Due to $\mathrm{CH}_{3}$ bending [24] \\
\hline 1383 & 1384 & 1380 & Due to $\mathrm{CH}_{3}$ bending [24] \\
\hline 1456 & 1455 & 1456 & Involves $\mathrm{CH}_{2}$ and $\mathrm{CH}_{3}$ bending [24] \\
\hline 1458 & 1458 & 1460 & Involves $\mathrm{CH}_{2}$ and $\mathrm{CH}_{3}$ bending [24] \\
\hline- & 1604 & 1614 & $\begin{array}{l}\text { Conjugated } C=C\left(1600 \mathrm{~cm}^{-1}\right) \text {; aryl-substituted } C=C\left(1625 \mathrm{~cm}^{-1}\right) \text {; } \\
\text { alkenyl } C=C \text { stretching }\left(1620-1680 \mathrm{~cm}^{-1}\right) \text { [27] }\end{array}$ \\
\hline 1650 & 1659 & 1649 & $\begin{array}{l}C=C \text { double bond stretching [22]; alkenyl } C=C \text { stretching } \\
\left(1620-1680 \mathrm{~cm}^{-1}\right) \text { [27] }\end{array}$ \\
\hline- & 1675 & 1674 & Alkenyl C=C stretch $\left(1620-1680 \mathrm{~cm}^{-1}\right)$ [27] \\
\hline 1690 & 1690 & 1690 & $\begin{array}{l}\text { Due to carbonyl group }(\mathrm{C}=\mathrm{O}) \text { stretching vibrations and, } \\
\text { respectively, to carboxylic acid group [24] }\end{array}$ \\
\hline- & 1710 & - & $\begin{array}{l}\text { Due to carbonyl group }(\mathrm{C}=\mathrm{O}) \text { stretching vibrations and, } \\
\text { respectively, to ketone and/or carboxylic acid group [24] }\end{array}$ \\
\hline 1730 & 1729 & 1730 & $\begin{array}{l}\text { Due to carbonyl group }(\mathrm{C}=\mathrm{O}) \text { stretching vibrations and, } \\
\text { respectively, to ester [24] }\end{array}$ \\
\hline 2868 & - & 2868 & Alkyl stretching and an important level of methyl groups [24] \\
\hline 2934 & - & 2934 & $\begin{array}{l}\text { Alkyl stretching; for the } \mathrm{CH} \text { groups; an important level of methyl } \\
\text { groups [24] }\end{array}$ \\
\hline 2957 & 2957 & 2960 & $\begin{array}{l}\text { Methyl C-H asymmetric/symmetric stretching [27]; corresponding } \\
\text { to the alkyl stretching; for the methyl groups; an important level of } \\
\text { methyl groups [24] }\end{array}$ \\
\hline 3410 & 3404 & 3410 & $\mathrm{OH}$ stretching of alcohols and/or carboxylic acids [24] \\
\hline- & - & 3544 & $\begin{array}{l}\text { Hydroxy group, H-bonded } \mathrm{OH} \text { stretch; internally bonded } \mathrm{OH} \\
\text { stretching [27] }\end{array}$ \\
\hline- & - & 3566 & $\begin{array}{l}\text { Hydroxy group, H-bonded } \mathrm{OH} \text { stretch; internally bonded } \mathrm{OH} \\
\text { stretching [27] }\end{array}$ \\
\hline
\end{tabular}



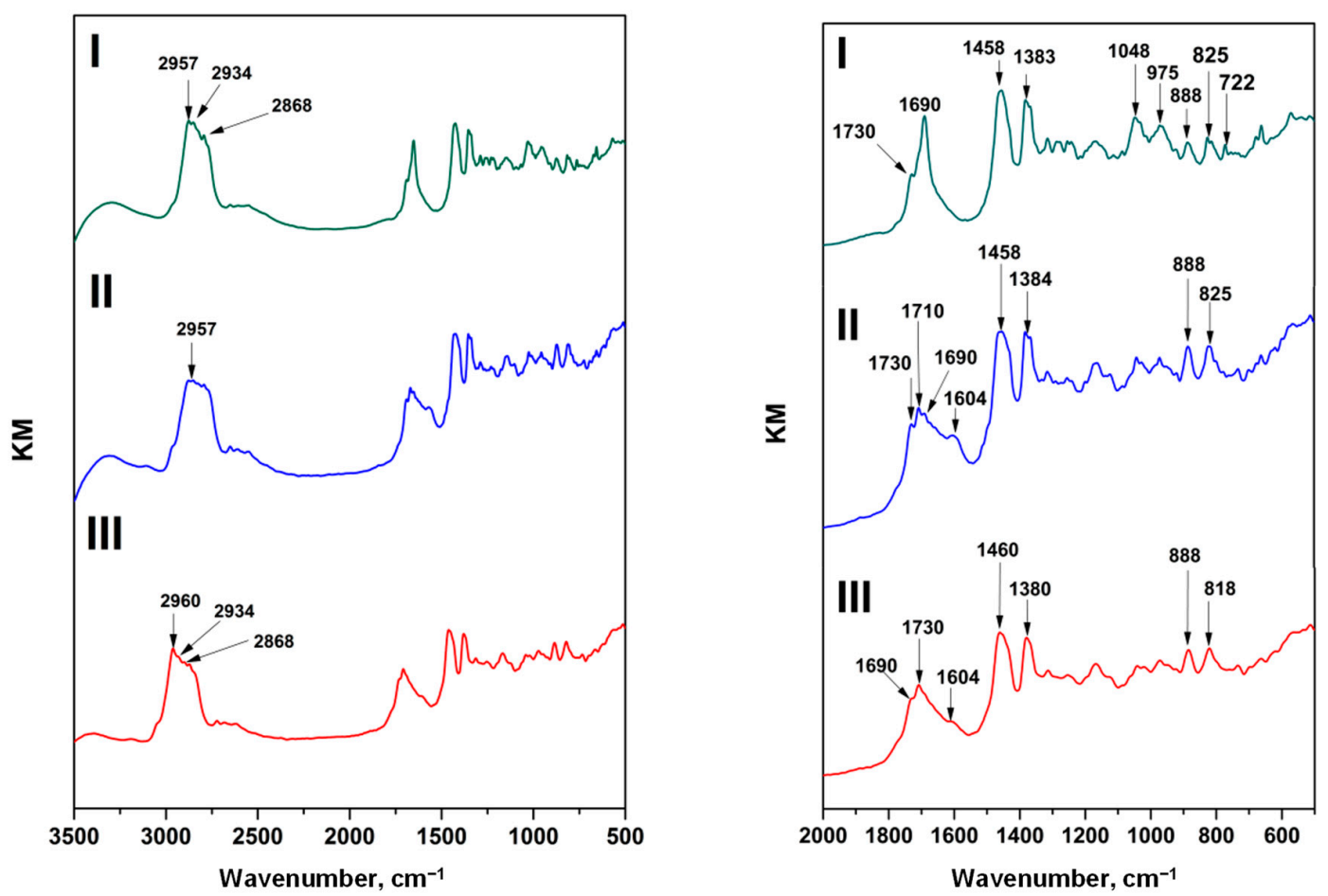

Figure 8. Kubelka-Munk-transformed diffuse reflectance spectra of resin varieties I, II, III from the island of Sumatra. The graph on the right depicts fingerprint region of the spectra $\left(2000-500 \mathrm{~cm}^{-1}\right)$.

\subsubsection{RS Analysis}

The Raman spectra of fossil resins from Sumatra show characteristic bands at 1650 and $\sim 1450 \mathrm{~cm}^{-1}$ (Table 3, Figure 9) which are considered diagnostic for the interpretation of the maturation processes of fossil resins [5,28-30]. The $\sim 1650 \mathrm{~cm}^{-1}$ band is related to $\mathrm{C}=\mathrm{C}$ bonds (unsaturated hydrocarbons), while the $\sim 1450 \mathrm{~cm}^{-1}$ band can probably be assigned to an asymmetric deformation of $\mathrm{CH}_{3}$ and $\mathrm{CH}_{2}$ groups [5]. The band at $1450 \mathrm{~cm}^{-1}$ is higher than that at $1650 \mathrm{~cm}^{-1}$ and the intensity ratio of the $1650 / 1450 \mathrm{~cm}^{-1}$ bands ranges from 0.39 (variety I) to 0.43 (variety III) and 0.44 (variety II). Additional bands at $\sim 680 \mathrm{~cm}^{-1}$ and $\sim 730 \mathrm{~cm}^{-1}$ are here assigned to aromatic out-of-plane deformation [29]. The bands between 500 and $600 \mathrm{~cm}^{-1}$ can probably be assigned to ring deformation vibration of the alicyclic ring [30].

Table 3. FT-Raman band assignment.

\begin{tabular}{|c|c|c|c|}
\hline \multicolumn{3}{|c|}{ Raman Shift $\left(\mathrm{cm}^{-1}\right)$} & \multirow{2}{*}{ Proposed Assignment } \\
\hline Variety I & Variety II & Variety III & \\
\hline- & 600 & - & (?) $\mathrm{C}-\mathrm{C}$ modes of the alicyclic rings [30] \\
\hline 680 & 680 & 680 & aromatic out-of-plane deformation [29] \\
\hline 730 & 730 & 730 & $\begin{array}{l}\text { aromatic out-of-plane deformation; bands related to the degree of } \\
\text { maturation }\left(600-800 \mathrm{~cm}^{-1}\right)[5]\end{array}$ \\
\hline 800 & 800 & 800 & $\begin{array}{l}\text { C-C functional group-highly mixed in complex molecule } \\
\left(700-1260 \mathrm{~cm}^{-1}\right) \text { [31], bands related to the degree of maturation } \\
\left(600-800 \mathrm{~cm}^{-1}\right) \text { [5] }\end{array}$ \\
\hline 1360 & 1366 & 1360 & $\mathrm{CH}_{2}$ deformation [28] \\
\hline 1315 & 1315 & 1315 & $\mathrm{CH}_{3}$ umbrella mode $\left(\sim 1375 \mathrm{~cm}^{-1}\right)[28] ; \delta \mathrm{CH}_{2}, \delta \mathrm{CH}_{3}[30]$ \\
\hline 1450 & 1450 & 1450 & an asymmetric deformation of $\mathrm{CH}_{3}$ and $\mathrm{CH}_{2}$ groups $[6,31]$ \\
\hline 1658 & 1658 & 1658 & $\mathrm{C}=\mathrm{C}$ bonds (unsaturated hydrocarbons) $[6,31]$ \\
\hline
\end{tabular}




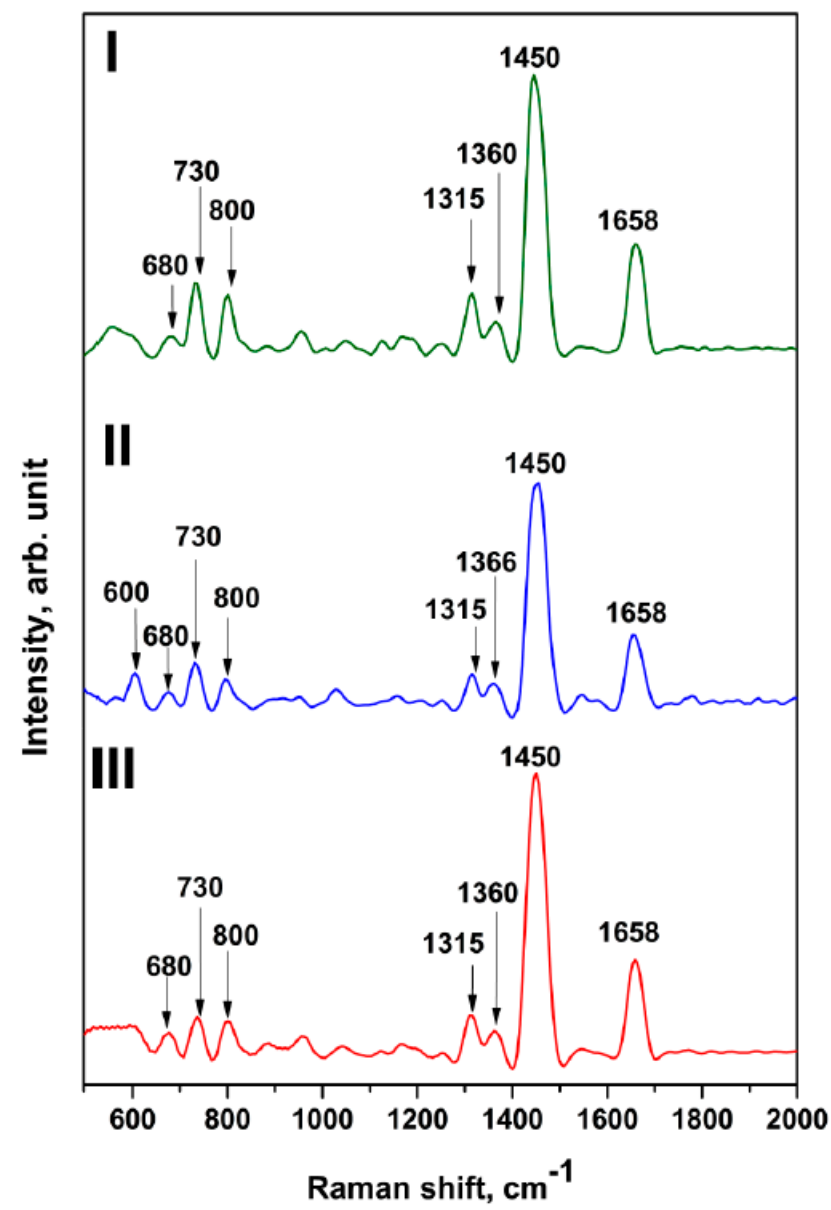

Figure 9. Raman spectra of resins varieties I, II and III from the island of Sumatra.

\section{Discussion}

The evolutionary history of fossil resins begins at the time of their exudation. Thus, the physical and chemical properties of the resins are shaped in their primary environment, depending on the biocoenosis of the amber-producing forests and on climatic conditions, including humidity and insolation [2]. Further alterations of the fossil resins take place in geological systems, where such factors as pressure, temperature and time influence their diagenetic pathways [2]. The results of microscopic and spectroscopic studies may be helpful for elucidation of a resin's origin, the steps in fossil resin formation processes and the subsequent alterations in the geological environment.

The factors which induced trees to produce resins in the Sundaland area during the Miocene epoch have not yet been elucidated. According to [32,33], resin exudation was the trees' response to beetle infestations enhanced by increased temperature. Nevertheless, the presence of volcanic activity as a geological factor responsible for Sumatran resin formation has been already proven in [3] by the presence of numerous mineral and rock inclusions in their structures, e.g., pyrogenic quartz, fragments of tonsteins and volcanic glass. In addition, the internal structure of resin variety III, especially the presence of droplets filled with resin variety I, was previously interpreted as resulting from boiling conditions during volcanic activity [3]. According to these authors, resin production was a tree's response to unfavourable climatic conditions influenced by volcanic explosions.

The resins were formed from different tree exudate outflows. The Sumatran resin variety I (transparent) is relatively poor in inclusions, and therefore it could be formed inside the trunk or within a specific part of the tree, e.g., branch junctions. Resin variety III (opaque) with a solid foam-like structure was probably formed subsequently outside the trunk, and therefore it contains many organic 
inclusions which may have been wind-transported from the surrounding ecosystem. The linear distribution of droplets suggests that the resin was formed as a result of the slow flow of resinous material with low viscosity. Therefore, this resin variety was the most affected by environmental factors (biological, climatic). Resin variety II seems to be the youngest-this resin seems to have become a binder for varieties I and III. It was formed as the tree's response to progressive deterioration in environmental conditions probably due to the increasing volcanism. It contains a great deal of dispersed coalified detritus material in its structure. Hence, it is assumed this resin could have lain on the surface layer of soil formed by decayed plant detritus, just under the resin-exuding trees.

Varieties II and III of the Sumatran resin exhibit similar FT-IR spectra in the fingerprint region (below $1800 \mathrm{~cm}^{-1}$ ), while variety I shows some differences. Strong differences are observed in the region of carbonyl and alcohol groups and unsaturated hydrocarbons. This may be caused by oxidation processes leading to the formation of oxygen-containing organic compounds. The oxidation processes may be induced by environmental (sunlight), biological and even geological (iron minerals) factors; however, it is still unknown whether the oxidation process occurred before burial or after formation of the fossil resin.

After deposition in the sedimentary basin, fossil resins underwent further alterations controlled by such factors as temperature, pressure, permeating fluids and time [2]. The proposed fossilization mechanism of the Sumatran specimens is polymerization through formation of carbon-carbon bonds between terpenoid molecules and elimination of water molecules from oxygen-containing compounds [8]. FT-IR and RS spectra show that the investigated resin specimens are mainly mixtures of various terpenoids. The infrared spectra show the presence of a cyclohexane ring (the band at $1043 \mathrm{~cm}^{-1}$, which is characteristic of ring deformation vibration). Moreover, Raman and infrared spectra show the presence of an aromatic ring $\left(1600 \mathrm{~cm}^{-1}\right.$ FT-IR band; $730 \mathrm{~cm}^{-1}$ and $\sim 680 \mathrm{~cm}^{-1}$ RS bands). This suggests that aromatization of the cyclohexane ring was the part of the fossilization process. The presence of carboxylic, ester and hydroxyl groups, as well as a terminal methylene group $=\mathrm{CH}_{2}$ suggests that fossilization occurred through formation of unsaturated $\mathrm{C}=\mathrm{C}$ bonds and their subsequent oxidation to form carboxylic and hydroxyl groups. Following this, the process was probably the cross-linking of compounds through formation of ester bonds. Plant exudates contain various organic compounds, such as phenols, alcohols and carboxylic acids, that may form polymer-like structures via esterification reactions induced by fossilization processes. The band characteristic of alcohol and large-molecule skeletal vibration overlaps with bands that indicate presence of epoxides or peroxides $\left(865,1165\right.$ and $\left.1265 \mathrm{~cm}^{-1}\right)$ or peroxides $\left(830-890 \mathrm{~cm}^{-1}\right)$.

The degree of a resin's maturation depends not only on the age of the sample but also on its geological history, as recorded in its physical and chemical properties [5,6]. The microhardness of all the resin specimens was very low in comparison to other Tertiary resins, e.g., Bitterfeld glessite (vide [34]). In contrast, the Raman band intensity ratio $1650 / 1450 \mathrm{~cm}^{-1}$ is very low, and comparable to older resins, e.g., Baltic amber (succinite) [6,30] which suggests loss of a double bond in polymerization. However, a higher degree of polymerization should have resulted in hardening of the resin. Therefore, the loss of the double bond may be a result of an oxidation process induced, for example, by volcanic activity in the region where resin was formed [3,8]. Volcanism as a source of heating is also suggested by the fact that Sumatran resins exhibit a relatively high maturation grade according to the Raman spectroscopy, which was not expected for resins of Miocene age. Therefore, time could not have been the only factor determining the fossilization mechanisms.

Additionally, the FT-IR spectra of resin varieties II and III revealed the presence of the $\sim 1600 \mathrm{~cm}^{-1}$ band usually assigned to fluorescent aromatic compounds. UV-microscopic imaging shows a higher intensity of blue light in varieties III and II compared to variety I. Fluorescence analysis of Sumatran fossil resins will be a subject of further study, together with their chemical composition. The occurrence of aromatic hydrocarbons in fossil resins from swamp depositional systems is very probable, due to the reducing environment, which is favourable for aromatization of compounds contained in plant exudates. 


\section{Conclusions}

1. Fossil resin from the island of Sumatra (Jambi Province, Sarolangun mine) occurs in three varieties, which differ macroscopically in their colour and transparency.

2. Resin specimens were formed from exudates from different times and locations, and thus they varied in clarity, inclusion content, maturation degree and fluorescence properties.

3. Aromatization of the cyclohexane ring was found to be part of the fossilization mechanism. This is supported by consideration of the reducing environment of the swamp where the resins were deposited and buried.

4. The maturation grade of fossil resins assessed via Raman spectroscopy was higher than expected for resins of Miocene age.

5. Volcanism, which was previously documented as a factor determining the increased resin production during the Miocene epoch, was also responsible for the relatively high maturation grade of the fossil resins.

Acknowledgments: The authors are grateful to Jacek Szczerba and Robert Girulski for providing specimens of Sumatran resin for the research. The Reviewers are greatly acknowledged for their friendly and helpful comments on the manuscript. This study was supported by statutory grant (AGH University of Science and Technology) and research project No. 61.2801.1502.000 (The Polish Geological Institute-National Research Institute).

Author Contributions: Beata Naglik, Barbara Kosmowska-Ceranowicz, Przemysław Drzewicz, Magdalena Dumańska-Słowik and Lucyna Natkaniec-Nowak designed the experiments, interpreted the data and wrote the paper. Jakub Matusik, Marian Wagner, Rastislav Milovsky, Paweł Stach and Arkadiusz Szyszka performed the experiments and prepared figures and photographs.

Conflicts of Interest: The authors declare no conflict of interest.

\section{References}

1. Tomkeieff, S.I. Coals and Bitumens and Related Fossil Carbonaceous Substances: Nomenclature and Classification; Pergamon Press: Oxford, UK, 1954.

2. Ragazzi, E.; Alexander, R.S. (Eds.) Amber. In Encyclopedia of Geobiology; Springer: Dordrecht, The Netherlands, 2011; pp. 24-36.

3. Kosmowska-Ceranowicz, B.; Sachanbiński, M.; Łydżba-Kopczyńska, B. Analytical characterization of "Indonesian amber" deposits: Evidence of formation from volcanic activity. Baltica 2017, 30, 55-60. [CrossRef]

4. Kosmowska-Ceranowicz, B. Bursztyn Battycki $i$ Inne Żywice Kopalne [Baltic Amber and Other Fossil Resins]; The Museum of the Earth of the Polish Academy of Sciences: Warsaw, Poland, 1993; 141p. (In Polish)

5. Jehlička, J.; Villar, S.E.J.; Edwards, H.G.M. Fourier transform Raman spectra of Czech and Moravian fossil resins from freshwater sediments. J. Raman Spectrosc. 2004, 35, 761-767. [CrossRef]

6. Winkler, W.A. Raman spectroscopic approach to the maturation process of fossil resins. J. Raman Spectrosc. 2001, 32, 59-63. [CrossRef]

7. Kosmowska-Ceranowicz, B. Bursztyn z Borneo-największe na świecie złoże żywicy kopalnej (The greatest fossil resin deposit in the world). Prz. Geol. 1994, 7, 576-578, (In Polish with English Summary).

8. Brackman, W.; Spaargaren, K.; Van Dongen, J.P.C.M.; Couperus, P.A.; Bakker, F. Origin and structure of the fossil resin from an Indonesian Miocene coal. Geochim. Cosmochim. Acta 1984, 48, 2483-2487. [CrossRef]

9. Langenheim, J.H. Higher plant terpenoids: A phytocentric overview of their ecological roles. J. Chem. Ecol. 1994, 20, 1223-1280. [CrossRef] [PubMed]

10. Lambert, J.B.; Levy, A.J.; Santiago-Blay, J.A.; Wu, Y. Nuclear Magnetic Resonance Characterization of Indonesian Amber. Life: Excitement Biol. 2013, 1, 136-155. [CrossRef]

11. Leelawatanasuk, T.; Wathanakul, P.; Paramita, S.; Sutthirat, C.; Sriprasert, B.; Bupparenoo, P. The characteristic of amber from Indonesia. Aust. Gemmol. 2013, 25, 142-145.

12. Schmidt, A.R.; Jancke, S.; Lindquist, E.E.; Ragazzi, E.; Roghi, G.; Nascimbene, P.C.; Schmidt, K.; Wappler, T.; Grimaldi, D.A. Arthropods in amber from the Triassic Period. Proc. Nat. Acad. Sci. 2012, 109, 14796-14801. [CrossRef] [PubMed]

13. Saint Martin, S.; Saint Martin, J.P.; Girard, V.; Grosheny, D.; Néraudeau, D. Filamentous micro-organisms in Upper Cretaceous amber (Martigues, France). Cretac. Res. 2012, 35, 217-229. [CrossRef] 
14. Kosmowska-Ceranowicz, B.; Vávra, N. Infrared Spectra of Fossil Resins, Subfossil Resins and Selected Imitation of Amber; Polish Academy of Science Museum of Earth: Warsaw, Poland, 2015.

15. Kosmowska-Ceranowicz, B. Glessite from Malesia and Indonesia. In Bursztyn w Polsce i na Świecie (Amber in Poland and in the World), 2nd ed.; Wydawnictwo Uniwersytetu Warszawskiego: Warsaw, Poland, 2017; pp. 1-310. (In Polish)

16. Krumbiegiel, G.; Kosmowska-Ceranowicz, B. Vorkommen von Glessit, Siegburgit (?) und Krantzit in Tertiär Mitteldeutschlands (Bitterfeld, Niederlausitz). Fundgrube 1990, 26, 78-81. (In German)

17. Krumbiegiel, G. Glessit, ein tertiäres Harz von Bedecktsamern. Fossilien 1993, 10, 83-90. (In German)

18. Kosmowska-Ceranowicz, B.; Krumbiegel, G.; Vávra, N. Glessit, ein tertiäres Harz von Angiospermen der Familie Burseraceae. N. Jb. Geol. Paläont. Abh. 1993, 187, 299-324. (In German)

19. Lambert, J.B.; Johnson, S.C.; Shawl, C.E.; Poinar, G.O. Fossil resin from Asia. Anc. Biomol. 1999, 3, $29-35$.

20. Adiwidjaja, P.; De Coster, G.L. Pre-Tertiary paleotopography and related sedimentation in South Sumatra. In 2nd Annual Convention Proceedings; Indonesian Petroleum Association: Jakarta, Indonesia, 1973; pp. 89-103.

21. Young, R.; Atkinson, C.D. A review of Talang Akar Formation (Oligo-Miocene) reservoirs in the offshore areas of Southeast Sumatra and Northwest Java. In Clastic Rocks and Reservoirs of Indonesia: A Core Workshop; Indonesian Petroleum Association: Jakarta, Indonesia, 1993; pp. 177-210.

22. Friederich, M.C.; Moore, T.A.; Flores, R.M. A regional review and new insights into SE Asian Cenozoic coal-bearing sediments: Why does Indonesia have such extensive coal deposits? Int. J. Coal Geol. 2016, 166, 2-35. [CrossRef]

23. Barber, A.J.; Crow, M.J.; Milsom, J.S. (Eds.) Sumatra: Geology, Resources and Tectonic Evolution; Geological Society of London: London, UK, 2005; Memoirs No. 31.

24. Guiliano, M.; Asia, L.; Onoratini, G.; Mille, G. Applications of diamond crystal ATR FTIR spectroscopy to the characterization of ambers. Spectrochim. Acta Part A Mol. Biomol. Spectrosc. 2007, 67, 1407-1411. [CrossRef] [PubMed]

25. Truică, G.I.; Teodor, E.D.; Litescu, S.C.; Radu, G.L. LC-MS and FT-IR characterization of amber artefacts. Cent. Eur. J. Chem. 2012, 10, 1882-1889.

26. Beck, C.; Wilbur, E.; Meret, S.; Kossove, D.; Kermani, K. The infrared spectra of amber and the identification of Baltic amber. Archaeometry 1965, 8, 96-109. [CrossRef]

27. Coates, J. Interpretation of infrared spectra, a practical approach. Encycl. Anal. Chem. 2000. [CrossRef]

28. Edwards, H.G.M.; Farwell, D.W. Fourier transform-Raman spectroscopy of amber. Spectrochim. Acta Part A Mol. Biomol. Spectrosc. 1996, 52, 1119-1125. [CrossRef]

29. Moreno, Y.M.; Christensen, D.H.; Nielsen, O.F. An NIR-FT Raman spectroscopic study of amber. Asian J. Spectrosc. 2000, 4, 49-56.

30. Brody, R.H.; Edwards, H.G.M.; Pollard, A.M. A study of amber and copal samples using FT-Raman spectroscopy. Spectrochim. Acta Part A Mol. Biomol. Spectrosc. 2001, 57, 1325-1338. [CrossRef]

31. Adar, F. Introduction to Interpretation of Raman Spectra Using Database Searching and Functional Group Detection and Identification. Spectroscopy 2016, 31, 16-23.

32. Bąk, M.; Natkaniec-Nowak, L.; Drzewicz, P.; Czapla, D.; Bogdasarov, M. Ambrosia-like fungi in fossil resin from Jambi Province in Sumatra Island-Possible phoretic organisms interacted with invaded insects. In Proceedings of the 17th Czech-Slovak-Polish Palaeontological Conference, Krakow, Poland, 20-21 October 2016; Abstract Volume 23.

33. Natkaniec-Nowak, L.; Drzewicz, P.; Bąk, M.; Matusik, J.; Kowalczyk, J.; Bogdasarov, M.; Ivanina, A.V. Fossil resins from Jambi province (Sumatra, Indonesia)—Proxy indicators of palaeonvironment and palaeoclimate of Sundaland. In Proceedings of the Third International Conference Viet-Pol, Hanoi, Vietnam, 12-15 November 2016; pp. 230-231.

34. Matuszewska, A.; Gołąb, A. Próba wykorzystania parametru mikrotwardości żywic kopalnych i sztucznych, jako cechy klasyfikacyjnej (An attempt at using the parameter of the microhardness of fossil and artificial resins as a classification feature). Bursztynisko 2008, 31, 56-61.

(C) 2018 by the authors. Licensee MDPI, Basel, Switzerland. This article is an open access article distributed under the terms and conditions of the Creative Commons Attribution (CC BY) license (http:// creativecommons.org/licenses/by/4.0/). 